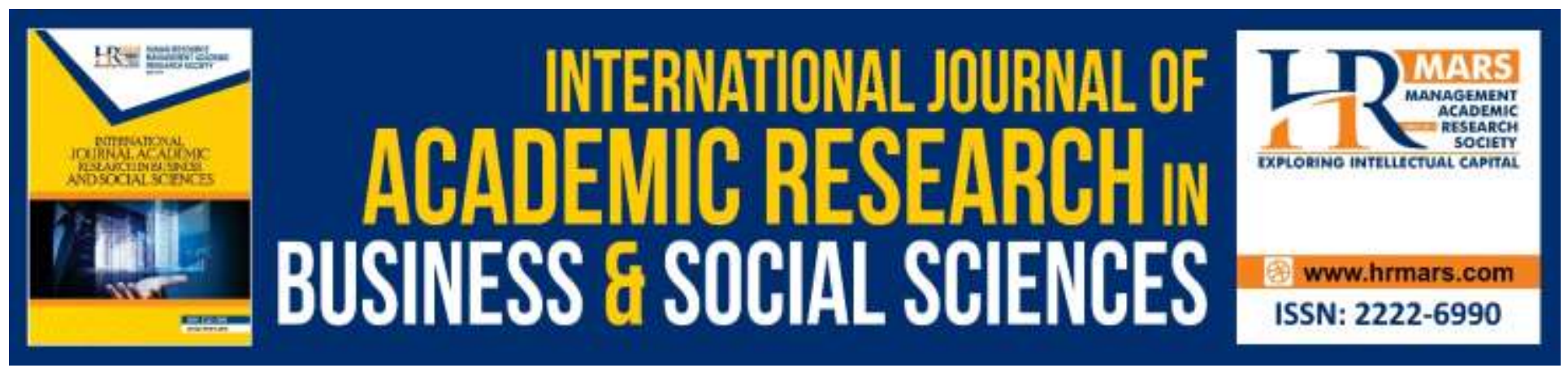

\title{
Determinants of Job stress among Non-Managerial Restaurant Employees in Klang Valley, Malaysia
}

\section{Hazrina Ghazali, Farah Wahida Amran, and Siti Fatimah Mohamad}

To Link this Article: http://dx.doi.org/10.6007/IJARBSS/v10-i3/7094

DOI:10.6007/IJARBSS/v10-i3/7094

Received: 05 February 2020, Revised: 22 February 2020, Accepted: 12 March 2020

Published Online: 24 March 2020

In-Text Citation: (Ghazali et al., 2020)

To Cite this Article: Ghazali, H., Amran, F. W., \& Mohamad, S. F. (2020). Determinants of Job stress among NonManagerial Restaurant Employees in Klang Valley, Malaysia. International Journal of Academic Research in Business and Social Sciences, 10(3), 811-822.

Copyright: (C) 2020 The Author(s)

Published by Human Resource Management Academic Research Society (www.hrmars.com)

This article is published under the Creative Commons Attribution (CC BY 4.0) license. Anyone may reproduce, distribute, translate and create derivative works of this article (for both commercial and non-commercial purposes), subject to full attribution to the original publication and authors. The full terms of this license may be seen at: http://creativecommons.org/licences/by/4.0/legalcode

Vol. 10, No. 3, 2020, Pg. 811 - 822

Full Terms \& Conditions of access and use can be found at http://hrmars.com/index.php/pages/detail/publication-ethics 


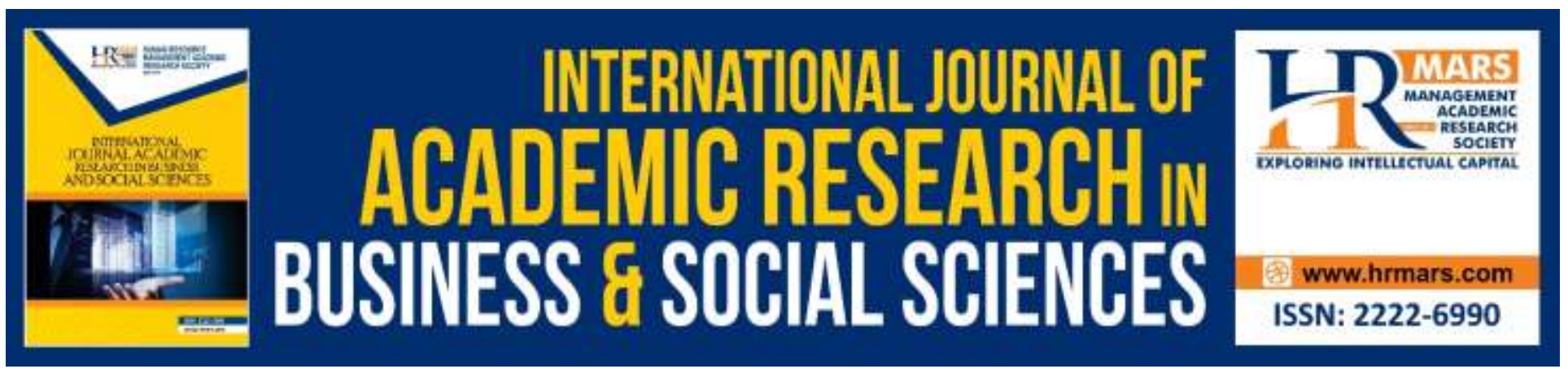

\title{
Determinants of Job stress among Non-Managerial Restaurant Employees in Klang Valley, Malaysia
}

\author{
Hazrina Ghazali, Farah Wahida Amran, and Siti Fatimah Mohamad \\ Department of Food Service and Management, Faculty of Food Science and Technology, Universiti \\ Putra, Malaysia, 43400 UPM, Serdang, Selangor, Malaysia
}

\begin{abstract}
Despite positive growth of restaurant industry in Malaysia but on the other side of coin, this industry always associated with having low pay, long working hours, lack of benefits, hard work, physically exhausting, and underappreciated thus increasing job stress among employees. The job-related stress is a growing concern among the restaurant operators as it has a significant impact on the performance and productivity of employees. Additionally, excessive and unmanageable stress can be damaging to employees' health as it affects their mental and physical wellbeing. Therefore, the aim of this study was to identify possible determinants and its influence towards job stress at workplace. The primary data of this study was derived from quantitative method, strictly to Malaysian non-managerial employees only and were distributed to 700 employees who were currently working in casual dining restaurants in Klang Valley area. After screening and data checking, a total of 487 self-completed questionnaires were usable for analysis with $69.6 \%$ of response rate. A multiple regression was run to predict job stress and three variables were used that are work environment, workload, and job autonomy. Results found that work environment and workload were statistically significantly predictor of job stress with $F(4,483)=28.131, p<.0005, R^{2}=.149$. These two variables added statistically significantly to the prediction, $p<.05$ and will be discussed further in this paper. Findings obtained in this study could suggest to owners and restaurant operators to highlight factor that could contribute to job stress and strategize proactive measures to minimize stress and ultimately retain their employees in the industry.
\end{abstract}

Keywords: Job Stress, Employees, Casual Dining Restaurant, Klang Valley Malaysia

\section{Introduction}

Nowadays, in the fastest growing of food service industry, casual dining restaurant has become one of the trends all over the world. In these modern days, urban lifestyle makes the fast-casual dining to be issued as family dining style restaurant that offer moderate price but slightly upscale compared to fast food industry. Casual dining restaurant is a moderate-upscale dining that provides relaxed atmosphere and food items with reasonable price where it focus on themes in menu, service, and 
INTERNATIONAL JOURNAL OF ACADEMIC RESEARCH IN BUSINESS AND SOCIAL SCIENCES Vol. 10, No. 3, March, 2020, E-ISSN: 2222-6990 ¿ 2020 HRMARS

décor and offer full service to the diners (Nasyira, 2014; Lynn, 2009). Casual dining restaurant divided according to their price range, the higher price range guest cheque average is RM40-RM50 while the lower price ranges between RM10-RM20 (Euromonitor International, 2012). It is somewhat more upscale than fast food restaurant.

Casual dining can be any number of themes, from Italian to Thai cuisine. Examples of casual dining restaurant in Malaysia are Secret Recipe, Kenny Rogers Roaster, Nando's and Absolute Thai Restaurant. As for 2016, Secret Recipe Cakes \& Café made 7\% value share in the year, hence, led fullservice restaurants in Malaysia (Euromonitor International, 2017). Hectic schedules in urban cities and income increases also contribute to increasing number of consumers dine out during weekdays or even weekend (Euromonitor International, 2016). Adding to that, the increasing in number of dining out patrons also contribute to the expanding of food and beverage services industry that mostly dominated by the people in urban area and has higher income (Sulaiman \& Haron, 2013). On the similar note, the urbanization process in Malaysia has changed the dining pattern due to the hectic lifestyle in the urban area (Basri, Ahmad, Anuar \& Ismail, 2016). Thus, the fast growth of restaurants in Malaysia is the reason and the best choice to dine and satisfy their hunger (Ahmad, Ghazali, \& Othman, 2013).

As the number of casual dining restaurant increase in Malaysia, the number of employees needed to support this industry also increase. This is because within this industry, more work positions are offered for the people to meet the labor needs for the industry. According to Ereno, Andrade, Miyauchi, Salinda, Arevalo and Reyes (2014), the demand for human workforce has escalated as the demand of food is getting escalated too. On the other perspective, due to positive growth of casual dining require employees who are working in this industry to be mentally and physically ready for the purpose of meeting customers demand.

However, the employees of casual dining restaurant also faced the stress-related problem at their work place. Stress at workplace also happened in the restaurant industry. The examples of stress observed are derived mainly from work overload such as understaffing, temporary staff shortages, unrealistic task criteria also bullying (Rowley \& Purcell, 2001). Working in the restaurant industry is different from other industry and it is a people-oriented business. This industry not only required employees to work for long hours, work in shift, do repetitive tasks, faced fussy customers but also to accept unattractive salary, slow promotion, lack of benefits and inefficient management. These realities contributed to the stress for decades and still be the major problem and concern in the industry (Birdir, Tepeci \& Saldamli, 2003).

In Malaysia, the increase of job stress problem is such a famous and common issue among the Malaysian organization (Rozi, 2015). The employees of food service industry and serving-related occupations in 2004-2006 period of time had reported to be the second highest incident (10.3\%) of major depressive episodes due to the work-related stress (Pizam, 2008; Tse, 2012). The increasing number of food service industry Malaysia has increased over the years caused the management level to face a competitive pressure due the growing demands of food service industry. This is because, most of the employees see their work as stressful or extremely stressful as they need to meet the 
INTERNATIONAL JOURNAL OF ACADEMIC RESEARCH IN BUSINESS AND SOCIAL SCIENCES

Vol. 10, No. 3, March, 2020, E-ISSN: 2222-6990 @ 2020 HRMARS

needs of the organization (Mukosolu et al., 2015). According to the Ling and Bhatti (2014), stated that each employee will feel the job stress once in their workplace as it always happened in every organization. As a consequent, in most of the organization, the employees mainly will become victims of stress. As a result, it will become as a challenge for the employer because this issue is exist in employment world (Hart, 1990; Karim, 1980; Ling \& Bhatti, 2014).

\section{Literature Review \\ Job Stress}

Job stress is such a worldwide serious factor that affects the employee's physical and mental condition as well as to the well-being of the organization (Mukosolu, Ibrahim, Rampal, \& Ibrahim, 2015). This problem always and frequently present in today's organization and the cost of these scenarios cut across the level of society (Sathasivam, Malek, \& Abdullah, 2015). In recent years, most of the researchers had made a great progress in understanding several aspects of stress phenomenon in term of organizational behavior. According to Mukosolu et al., (2015) stated that the researchers around the globe had indicated that the prevalence of stress of employees in institution likes university personnel has been increased up to 2340 cases over 100,000 people where most of them had lack of support, anxiety and depression. Thus, from this data, it shows that the stress level at workplace had given such huge impact towards the productivity of employees in organization.

\section{Work Load}

Workload refers to amount of work need to be done by an employee at workplace. Workload can be defined as a task that cannot be done within the requirement period of time because of the excessive work and hard to be complete (Cooper, Dewe and Driscoll, 2001). Rizzo (1970) also defined the workload as an incompatibility of the requirements, resources and time constraints to finish the job. According to the Blackmore, Robertson, Stanfield, Weller, Munce, Zagorski and Steward (2007) also had stated that one of the factors which was contributed to the job stress is high job strain. High workload with two or more tasks is a primary cause for decreased performance of employees and can caused the job stress in their work place (Macdonald, 1984; Radzali, Ahmad). Pavesic and Baymer (1990) also mentioned that one of the reasons caused the young and qualified people working in accommodation industry turn to leave the job is because of the excessive workload that may resulted in work stress instead of long working hour and low wage. Bitner, Booms and Mohr (1994) identified that people whose are working in food and beverage industry are the group of people who will experienced the most of unhappy feeling while working. The excessive workload that someone cannot be withstood and control of will lead to the job stress. The stress condition with a heavy workload is closed to the Burnout Syndrome. This syndrome is defined as "progressive and gradual process caused by a mismatch between the demand for employees and job demand" (Ardic and Polatci, 2009:21).

In the hospitality industry, Shani and Pizam (2009) had come out with the hypothesis that the substantial rate of depression was caused by the high rate of burnout syndrome which is happened because of the excessive workload. Therefore, there were a few factors that had contributed to the work stress which are the workload and working environment (Bradberry, 2016) and emotional exhaustion (Maslach and Jackson, 1981). The starting point that accesses the limitation of one's 
ability to do the job and the feeling of failing is the emotional exhaustion (Aksu, Temeloglu, 2015). According to the previous research by Freundenberger (1974) the study had more emphasize on the problem rises from the inability of the people to fulfil the requirement of their tasks due to the excessive workload that may resulting them to be in the state of stress. Maslach and Jackson (1981) stated that this condition as emotional exhaustion that also caused the negation syndrome happens in response to the stressfulness of one's professional life. In addition, the people who are working at similar capacity are actually undergoes the syndrome of decreasing in their personal achievement, emotional exhaustion and loss of self (Maslach, Jackson and Leiter, 1996).

\section{Work Environment}

Occupational Safety and Health Act (OSHA) had defines the work environment as the place where one or more employees are working or as present with the requirement of their employment, and it is includes the physical locations, equipment or any material used by the employees during the course of their work. Zohar (1994) had found out that the environment of works is one of the factors that resulting in burnout syndrome due to over stress. According to Pearson and Moomaw (2005), working environment is also a factor that causes people to have the unpleasant feelings towards their works such as frustration, anger, worry, tension, depression and anxiety. This will lead to the dissatisfaction of job among the employees and it might cause the employee for not performing well resulted from the low quality of productivity (John, 2014). Stress Management Tips (2010) stated that stress in work place frequently gives a great impact towards the individual performance. This statement was supported by American Psychological Association (2011) where work place might create physical stress for the employees due to the noise, poor lighting, lack of privacy, facilities and so on. Thus, this unhealthy environment might contribute to the psychologically stressful conditions of employees at their workplace.

\section{Job Autonomy}

Job autonomy refers to freedom employees have while working at workplace. Job autonomy also can be defined as the extent of conduct an employee has over his or her decisions and thoughts (Liu, Spector, \& Jex, 2005). Also, job autonomy is the extent to which an employee has his/her own liberty and freedom in determining the pace, order approaches in completing a task (Volmer, Spurk and Niessen, 2012). Autonomy makes employees feel free and can control their tasks (Deci et al., 1989). $\mathrm{Ng}$ and Feldman (2014), found that not all employees who perceived high autonomy produced more positive job productivity, better lifestyle, and show positive work performance (Ng and Feldman, 2014). Thus, job autonomy may be considered as one of the important stress resources that promotes job stress.

\section{Research Framework}

The research framework of this study is grounded based on previous theoretical and empirical studies. The proposed research framework, as shown in Figure 2.1, demonstrates the linkages of factors that can determine the likelihood of employee's job stress. Work environment, workload and job autonomy are listed as independent variables whereas employee's job stress made up as the dependent variable. The casual dining restaurant industry was chosen as the field study because of 
INTERNATIONAL JOURNAL OF ACADEMIC RESEARCH IN BUSINESS AND SOCIAL SCIENCES Vol. 10, No. 3, March, 2020, E-ISSN: 2222-6990 @ 2020 HRMARS

its nature and the employment opportunities that the industry offers. The findings of this study are hoped to shed light on the job stress in the casual dining restaurant industry.

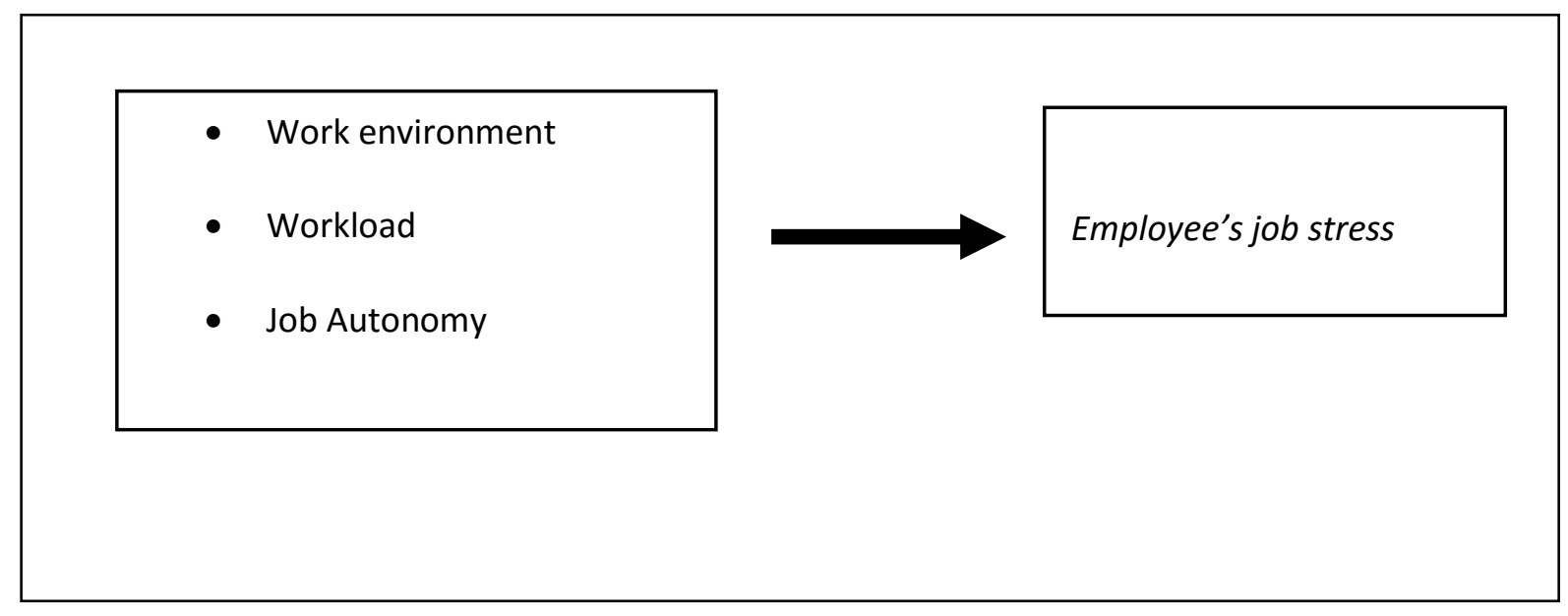

Figure 2.1: Research Framework

\section{Methodology}

Based on the objectives of this research, paper-pencil-questionnaires have been selected as the finest to undergo the process of collecting data from the respondents. Respondents are more truthful in answering questionnaires instead of going through face-to-face interviews, as to the fact that their responses remain anonymous (Leedy \& Ormrod, 2011). In this study, questionnaires were distributed to prospect respondents and then were collected back and the data collected was used for analysis purposes. The sampling location chosen was Klang Valley due to a great number of casual dining restaurants in Malaysia (Nasyira et al., 2014). It covered the area of capital city of Malaysia, Kuala Lumpur, and other cities, namely Shah Alam, Petaling Jaya, Klang, Subang Jaya, Ampang, Kajang, Putrajaya, Selayang and Sepang. The collection yielded a total of 487 usable questionnaires, giving a $69.6 \%$ of response rate. The population of the study is the employee of casual dining restaurant in Malaysia. The sampling frame comprised of the non-managerial of casual dining restaurants in the Klang Valley area. Non-managerial employees were chosen because they had the same job scope, nature of work and same workload. Thus, it is hoped it will give more significant results. The survey questionnaires are distributed to employees of male and female aged from 18-50 years old, strictly to Malaysian citizen only, non-managerial position, and working at casual dining restaurants around Klang Valley area during the period of data collection. The employees also were advised that their participations were voluntarily and their identities will be kept anonymous.

\section{Results and Discussion}

\section{Demographic Characteristics of Respondents}

The survey sample included 700 employees of casual dining restaurant in Klang Valley, Malaysia. This study only focuses on non-managerial employees and of the 700 questionnaires distributed, only 487 responses were completed producing a response rate of $69.6 \%$. These data were then used for further analysis. Overall, the percentage of gender between male and female where female made up 
INTERNATIONAL JOURNAL OF ACADEMIC RESEARCH IN BUSINESS AND SOCIAL SCIENCES Vol. 10, No. 3, March, 2020, E-ISSN: 2222-6990 (C) 2020 HRMARS

of $53 \%$, while male comprised of $47 \%$ from the total respondents. A great number of them were singles $(94.3 \%)$ and the rest of the percentage was married (5.3\%). Majority of respondents were age between 21 to 30 years old (56.7\%) followed by those aged below 20 years old (39.2\%). Of the 487 respondents, only $0.2 \%$ was aged between 41 to 60 years old. It clearly shows that this study yielded a larger number of generation $\mathrm{Y}$.

In the demographic section as well, the employees were asked on how many hours they work in a day. For that, a slightly more than half of the employees which accounted for $58.3 \%$ had worked for 8 hours, $17.5 \%$ worked for 10 hours, followed by $12.9 \%$ of the employees had worked for more than 10 hours and lastly about $11.3 \%$ of employees had worked for 6 hours in a day. Also, results has found that $52.6 \%$ which equals to 256 respondents felt stress $1-2$ times in a week, followed by $18.9 \%$ which equals to 92 respondents felt stress 3-4 times in a week and 8.8\% which accounted for 43 respondents that felt stress every day. Table 1 below shows the details of the respondents.

Table 1: Demographic profile of respondents

\begin{tabular}{|c|c|c|c|}
\hline Variables & Category & Frequency (N) & Percentage (\%) \\
\hline \multirow[t]{2}{*}{ Gender } & Male & 229 & 47.0 \\
\hline & Female & 258 & 52.3 \\
\hline \multirow[t]{5}{*}{ Age } & Below 20 years old & 191 & 39.2 \\
\hline & 21 to 30 years old & 276 & 56.7 \\
\hline & 31 to 40 years old & 19 & 3.9 \\
\hline & 41 to 50 years old & 1 & 0.2 \\
\hline & 51 to 60 years old & 0 & 0 \\
\hline \multirow[t]{2}{*}{ Marital status } & Single & 459 & 94.3 \\
\hline & Married & 28 & 5.7 \\
\hline \multirow{4}{*}{$\begin{array}{l}\text { Hours of working in the } \\
\text { outlet per day }\end{array}$} & 6 hours & 55 & 11.3 \\
\hline & 8 hours & 284 & 58.3 \\
\hline & 10 hours & 85 & 17.5 \\
\hline & More than 10 hours & 63 & 12.9 \\
\hline \multirow[t]{5}{*}{ Frequency felt stress } & 1 to 2 times a week & 256 & 52.6 \\
\hline & 3 to 4 times a week & 92 & 18.9 \\
\hline & Everyday & 43 & 8.8 \\
\hline & Not at all & 90 & 18.5 \\
\hline & Others & 6 & 1.2 \\
\hline
\end{tabular}


INTERNATIONAL JOURNAL OF ACADEMIC RESEARCH IN BUSINESS AND SOCIAL SCIENCES Vol. 10, No. 3, March, 2020, E-ISSN: 2222-6990 @ 2020 HRMARS

\section{Multiple Linear Regression}

Table 2 was summary of the regression analysis of the study. The analysis of multiple regression with significant level of 0.05 was used to determine the main factor that influence employee's job stress. Based on the result, the $R$ value of this regression model was 0.307 . It means that there was positive and moderate relationship of employee job stress. On top of that, the $R^{2}$ value was 0.149 . Meaning that, $14.9 \%$ of variance being explained from the three (3) variables that are work environment, workload and job autonomy. These variables might influence the employee job stress. The high proportion of variance shows that high probability of this factor as a predictor towards the employee job stress. The highest variance value may be the most probable influencing factor on the employee job stress.

From the result in table 2 below, it could be summarized that the factors that affecting the employee job stress in casual dining restaurants in Klang Valley area were the work environment and workload. These findings are reasonable enough to propose that employees who experience high levels of job stress are less likely to be committed to the company. It also parallel to the previous studies stated by Tromp and Blomme, (2012) that job stress can be influenced by a number of workplace characteristics. Factors such as job stressors, stress at work and work environment lead employees to consider leaving their job (Tsaur and Tang, 2012). On the other hand, Karatepe (2013), stated that the job stressor which is workload was statistically significant correlation to employee's job stress. Also, excessive workload is one of the sources and evidence of stress at work and emotional depletion of employees.

Based on table 3, there were three (3) independent variables were measured in examining the employee's job stress. For that, the work environment and workload were significant to the significant level since the $p$ value was less than 0.05 . Thus, it stated that work environment and workload were the key in predicting the employee job stress. Other variable (job autonomy) was insignificant to the dependent variable in predicting the employee job stress. The $p$ values for the variable was more than the significant level (0.05), and thus it was not the crucial factor that influence the employee job stress. Work environment and workload shows there were a significant impact between workload towards job stress. This might be happened due to never ending demands, rapid pace and never enough hours in a day. This can upset employees work-life balance and indirectly increase the feeling of helplessness. Astianto (2014), says an overloading rate enables excessive energy use and overstress occurs, otherwise the overloading intensity enables boredom and saturation or under stress.

Moreover, the Standard Coefficients are used to determine the level of factors which influence employee job stress. Results show the work environment and workload $(\beta=-0.320, p=0.000$ and $\beta$ $=0.228, p=0.000$ ) influencing the employee job stress. From the results, it can be summarized that work environment and workload are the key factor of employee job stress among casual dining restaurant employees in Klang Valley. Therefore, it could be concluded that when work environment and workload is increasing, the employee job stress will increase too. This result can be expected due to the nature of work in the restaurant industry. Stress can arise as a result of pressure or tension that comes from dissonance between a person and his environment. 
INTERNATIONAL JOURNAL OF ACADEMIC RESEARCH IN BUSINESS AND SOCIAL SCIENCES

Vol. 10, No. 3, March, 2020, E-ISSN: 2222-6990 @ 2020 HRMARS

Table 2: Summary of regression analysis

\begin{tabular}{lcccc}
\hline Model & R & R Square & $\begin{array}{c}\text { Adjusted R } \\
\text { Square }\end{array}$ & $\begin{array}{c}\text { Std. Error of } \\
\text { the Estimate }\end{array}$ \\
\hline 1 & $0.386^{\mathrm{a}}$ & 0.149 & 0.143 & 0.83961 \\
\hline
\end{tabular}

R square $=0.149$; meaning that only $14.9 \%$ of variance in job stress was explained by work environment, workload and job autonomy

a. Predictors: (Constant), Work environment, workload, job autonomy

b. Dependent variable: Employee's job stress

Table 3: Result of Multiple Linear Regression Analysis

a. Dependent Variable: Job Stress

\begin{tabular}{lcclll}
\hline Model & $\begin{array}{l}\text { Unstandardized } \\
\text { Coefficients } \\
\text { B }\end{array}$ & Std. Error & $\begin{array}{l}\text { Standardized } \\
\text { Coefficients } \\
\text { Beta }\end{array}$ & t & Sig. \\
\hline (Constant) & 2.154 & .313 & & 6.883 & .000 \\
Work Environment & -.386 & .055 & -.320 & -7.708 & .000 \\
Workload & .411 & .076 & .228 & 5.404 & .000 \\
Job Autonomy & .033 & .050 & .030 & .661 & .509 \\
\hline \hline
\end{tabular}

Predictors:Work environment $(t=1.135, p=0.257)$

Workload $(t=5.960, p=0.000)$

Job autonomy $(t=1.266, p=0.206)$

\section{Discussion}

Generally, it is understandable that employees especially in restaurant industry felt stressed and burnt out from their daily job due to the nature of the job and work environment. Findings from this study of casual dining restaurant non-managerial employees hopefully shed light and offer solutions to managers and restaurant operators. Findings disclosed identified factors lead to job stress. The roles of the factors also have been highlighted and work environment and workload were found to be influential towards job stress. Additionally, the owner and restaurant operators should put extra concern on improving work environment and workload. With the proactive measures and strategies, employee's job stress can be minimised and ultimately increase job satisfaction and performance.

Work environment has been found to be a significant factor in determining employee job stress. Ineffective work environment such as little teamwork, bad managers, strenuous work lead to employee's job stress. When the work environment is in tense situation to employee, it will produce job stress and this will lead to negative and damaging effect to the emotions. The second factor that accumulated among Malaysian employees was the workload at workplace. Heavy and too much of workload and job stress have serious consequences towards employees. Also, heavy workload and a high level of job stress diminish service quality. Workload also may possibly affect the employee's 
creativity and productivity as it will distract their emotions (Hon et al., 2013b; Hon and Chan, 2013a). Thus, it is vital to the organizational managers and supervisors to understand the work environment and the workload and incorporate this knowledge into their strategic and operational decision making in order to overcome the job stress problem.

Additionally, it is important for restaurant operator and owner to pay their attention on the causes and effects of the job stress occur among their employees especially within the work place. The managerial level should be mandatorily aware of the stress-related problem as it is such a disease which is widely spread and easily affected people. Moreover, the awareness of the job-related stress is important to overcome as it is reflected the productivity and performance of employees in different type of organizations. This current research highlighted possible determinants that influence job stress among employees in restaurant industry.

When the relationship among the variables are cleared and achieved, it is hoped to guide the manager when they encountered these problems. The results can be used to assist and guide the managerial levels to implement specific retention strategies in the casual dining restaurant organization. Instead, this study also provides a better understanding of information and pictures of the key drivers of job stress of the casual dining restaurant employees in the casual dining restaurant industry for future research. Not only that, the results also can be used to educate restaurant practitioners in helping their employees to minimize stress. Once they have the knowledge and information about these factors, they can take corrective measures to eliminate these factors from the work-life of their employees. The actions too can be transformed into cares from the employer to the employee and when the trust has built between them, a strong mutual understanding can be created hence promoting a better image of the industry. Last but not least, this study also provides information and give view of the key drivers of job stress of the casual dining restaurant employees in the casual dining restaurant industry for future research.

\section{Corresponding Author}

Dr. Hazrina Ghazali

Department of Food Service and Management, Faculty of Food Science and Technology, Universiti Putra Malaysia, Selangor, Malaysia.

Email: hazrina@upm.edu.my

\section{References}

Aksu, M., \& Temeloglu, E. (2015). Effects of Burnout on Employees ' Satisfaction a Research at 3, 4 and 5 Star Hotels in Canakkale City Center, 6(1), 219-230.

American Psychological Association: Stress in the Workplace. (2011). Retrieved April 18, 2017, from https://www.apa.org/helpcenter/workplace-stress.aspx

Ardıç, K., \& Polatçı, S. (2009). Burnout Syndrome and the Other Side of the Medallion: Integration with the Business, Erciyes University Journal of Faculty of Economics and Administrative Sciences, 32: 21-46. 
INTERNATIONAL JOURNAL OF ACADEMIC RESEARCH IN BUSINESS AND SOCIAL SCIENCES Vol. 10, No. 3, March, 2020, E-ISSN: 2222-6990 ¿ 2020 HRMARS

Astianto, Anggit. (2014). Pengaruh stres kerja dan beban kerja terhadap kinerja karyawan pdam Surabaya. Jurnal. Surabaya: SekolahTinggi Ilmu Ekonomi Indonesia.

Birdir, K., Tepeci, M., \& Saldamli, A. (2003). Job stress in hospitality and tourism organizations: sources, consequences and management.

Bradberry, T. (2016). Overwork and stress are destroying us. Retrieved March 07, 2017, from https://qz.com/809752/stressful-work-environments-destroy-workers-mood-health-andproductivity/

Cooper, C. L., Dewe, P.J., \& O’Driscoll, M. P. (2001), Organizational Stress. A review and critique of theory, research and applications. London, UK : Sage Publications.

Deci, E. L.\& Ryan, R. M. (2000). The what and why of goal pursuits: Human needs and the selfdetermination of behaviour, Psychological Inquiry, 11(4), pp.227-268.

Ereno, J. R., Andrade, K. M., Miyauchi, S. I., \& Arevalo, R. R. (2014). Encountering and Countering Work Stress: a Multivariate Analysis of the Occupational Stressand Coping Mechanisms of Fast Food Restaurant Personnel in the Philippines, 10(8), 148-158.

Euromonitor International : Institutional Channels in Malaysia. (2016, September). Retrieved May 16, 2017, from h ttp://www.euromonitor.com/contract-foodservicein-malaysia/report

Freudenberger, H. J. (1974). Staff Burn-Out, Journal of Social Issues, 30 (1): 159-165.

Hon, A., \& Chan, W. (2013). The effects of group conflict and work stress on employee performance, Cornell Hospitality Quarterly, 54(2), Pp. 174-184.

Hon, A. H. Y., Chan, W. W.H., \& Lu, L. (2013). Overcoming work-related stress and promoting employee creativity in hotel industry: the role of task feedback from supervisor. International Journal of Hospitality Management. 33(2), $416 e 424$.

Ling, S. M., \& Bhatti, M. A. (2014). Work Stress and Job Performance in Malaysia Academic Sector: Role of Social Support as Moderator. British Journal of Economics, Management \& Trade Original Research Article British Journal of Economics Management \& Trade, 4(412), 19861998. https://doi.org/10.9734/BJEMT/2014/12098.

Liu, C., Spector, P., \& Jex, S. (2005). The relation of job control with job strains: A comparison of multiple data sources. Journal of Occupational and Organizational Psychology, 78(3), 325-336.

John, O. T. (2014). Influence of Work Environment on Workers Productivity. Kaduna Polytechnic.

Retrieved from

http://www.academia.edu/16534065/Influence_Of_Work_Environment_On_Workers_Prod uctivity

Karatepe, O. S. (2013). The effects of work overload and work-family conflict on job embeddedness and job performance the mediation of emotional exhaustion. International Journal of Contemporary Hospitality Management, 25(4), 614-634.

Leedy, P. D., \& Ormrod, J. E. (2011). Practical Research: Planning and Design, Ninth Edition. NYC: Merril.

Macdonald, W. (2006). The Impact of Job Demands and Workload on Stress and

Fatigue [Abstract]. Australian Psychologist,38(2),

102-117. doi:10.1080/00050060310001707107

Rozi, M. S. R. (2015). The Influence Of Job Stress Factors Toward Job Performance Among Royal Malaysian Police At Kuala Lumpur, (March). 
INTERNATIONAL JOURNAL OF ACADEMIC RESEARCH IN BUSINESS AND SOCIAL SCIENCES

Vol. 10, No. 3, March, 2020, E-ISSN: 2222-6990 C 2020 HRMARS

Mukosolu, O., Ibrahim, F., Rampal, L., \& Ibrahim, N. (2015). Prevalence of job stress and its associated factors among Universiti Putra Malaysia staff. Malaysian Journal of Medicine and Health Sciences, 11(1), 27-38.

Nasyira, M. N., Othman, M., \& Ghazali, H. (2014). Predictors of Intention to Stay for Employees of Casual Dining Restaurant in Klang Valley Area. International Food Research Journal, 21(3), 863-871.

Ng, T. W. H., \& Feldman, D. C. (2014). Subjective career success: A meta-analytic review. Journal of Vocational Behavior, 85(2),169-179.

Pavesic, D. V., and Brymer, R. A. (1990). Job Satisfaction: What's Happening to the Young Manager, Cornell Hotel and Restaurant Administration Quarterly, 30 (4): 90-96.

Pearson, L. C., Moomaw, W. (2005). The relationship between teacher autonomy and stress, work satisfaction, empowerment, and professionalism. Educ. Res. Q., 29(1): 37-53.

Radzali, F. M., Ahmad, A., \& Omar, Z. (2013). Workload, Job Stress, Family-To-Work Conflict and Deviant Workplace Behavior. International Journal of Academic Research in Business and Social Sciences, 3(12), 109-115. https://doi.org/10.6007/IJARBSS/v3-i12/417

Rizzo, J. R. (1970). Role Conflict and ambiguity in complex organizations. Administrative Science Quarterly, Vol. 15, No.2, 150-163

Sathasivam, K. V., Malek, M. D. H. A., \& Abdullah, A. F. (2015). Organizational Stressors and Job Stress Among Malaysian Managers: The Moderating Role of Personality Traits. International Journal of Social Work, 2(1), 1. https://doi.org/10.5296/ijsw.v2i1.7338.

Tromp, D. M., \& Blomme, R. J. (2012). The effect of effort expenditure, job control and work-home arrangements on negative work-home interference in the hospitality industry. International Journal of Hospitality Management, 31(4), 1213-1221.

Tsaur, S., \& Tang, Y. (2012). Job stress and well-being of female employees in hospitality: the role of regulatory leisure coping styles. International Journal of Hospitality Management, 31(4), 1038-1044.

Spector, P. E., Cooper, C. L., \& Aguilar-Vafaie, M. E. (2002a), A comparative study of perceived job stressor sources and job strain in American and Iranian Managers, Applied Psychology: An International Review, Vol. 51 No. 3, pp. 446-57.

Zohar, D. (1994). Analysis of Stress Profile in The Hotel Industry, International Journal of Hospitality Management, 13 (3): 219-231. 